\title{
BARRIERS OF TEACHER FORMATION IN THE IMPLEMENTATION OF DISTANCE LEARNING TECHNOLOGIES IN MODERN EDUCATION
}

\author{
BARREIRAS DA FORMAÇÃO DE PROFESSORES NA IMPLEMENTAÇÃO DE \\ TECNOLOGIAS DE ENSINO A DISTÂNCIA NA EDUCAÇÃO MODERNA
}

\author{
BARRERAS DE LA FORMACIÓN DE PROFESORES EN LA IMPLEMENTACIÓN DE \\ TECNOLOGÍAS DE APRENDIZAJE A DISTANCIA EN LA EDUCACIÓN MODERNA
}

\author{
Lenar Minnekhanovich MUKHAMETSHIN ${ }^{1}$ \\ Klara Khakimovna KARAMOVA ${ }^{2}$ \\ Leila Leonardovna SALEKHOVA ${ }^{3}$ \\ Salavat Fargatovich USMANOV ${ }^{4}$
}

ABSTRACT: The article is devoted to the problems of using distance educational technologies, which are barriers in the educational process. The authors investigate the possibilities considering technical features of the functioning of distance learning technologies and e-learning in the legislation, as well as the conditions and problems of using distance learning technologies and e-learning in the educational process. The relevance of the problem is in improving the formation of teachers for professional activities in the context of modern tendency in the informatization of education. Professional formation is based on the inclusion of innovative activities in the educational process of a pedagogical university aimed at organizing creative informational interaction of students and teachers in the process of mastering e-learning technologies. In accordance with the new amendments in the Federal Law "About Education" the problem of including distance educational technologies in schools is updated. In the article, the directions of teachers' professional formation for distance learning are defined, the main models of teachers' professional formation in the field of distance educational technologies at the stage of formation at a pedagogical university and advanced formation are listed as well. But there are barriers that impede the use of distance learning technologies and e-learning in the educational process. The difference between distance educational technologies and electronic education is whether there is a direct cooperation between the teacher and the student or not. If it is carried out using information technology, technical means, we are talking about e-learning. If the interaction is mediated, through the Internet for example, then this is distance learning. An educational organization has the right to use one or both forms of implementation in their educational program. It is

\footnotetext{
${ }^{1}$ Kazan Federal University (KPFU), Kazan - Russia. Assistant Lecturer of the Department of Bilingual and Digital Education, Institute of Philology and Intercultural Communication. ORCID: https://orcid.org/0000-00031735-5708. E-mail: mlenarm@mail.ru

${ }^{2}$ Kazan Federal University (KPFU), Kazan - Russia. Associate Professor of the Department of Design and National Arts, Institute of Philology and Intercultural Communication. Candidate of Pedagogical Sciences. ORCID: https://orcid.org/0000-0002-2973-2243. E-mail: klara karamova kazan@mail.ru

${ }^{3}$ Kazan Federal University (KPFU), Kazan - Russia. Professor of the Department of Bilingual and Digital Education, Institute of Philology and Intercultural Communication. Doctor of Pedagogical Sciences. ORCID: https://orcid.org/0000-0002-8177-3739. E-mail: salekhova2009@gmail.com

4 Kyrgyz-Russian Slavic University (KRSU), Bishkek - Kyrgyzstan. Professor, Dean of the School of International Relations. Doctor of Technical Sciences. ORCID: https://orcid.org/0000-0002-5019-0880. E-mail: usmanov@krsu.edu.kg
}

RPGE-Revista on line de Política e Gestão Educacional, Araraquara, v. 25, n. esp. 1, p. 398-407, mar. 2021. DOI: https://doi.org/10.22633/rpge.v25iesp.1.14976 
important to prepare future teachers for the use of distance learning technologies in professional activities in the global process of informatization and digitalization of education.

KEYWORDS: Barriers. Social and pedagogical conditions. Quality management. Distance educational technologies. Standard. Information technologies.

RESUMO: $O$ artigo se dedica à problemática do uso das tecnologias de educação a distância, que constituem barreiras no processo educacional. Os autores investigam as possibilidades considerando as características técnicas de funcionamento das tecnologias de educação a distância e e-learning na legislação, bem como as condições e problemas do uso de tecnologias de educação a distância e e-learning no processo educacional. A relevância do problema está em aprimorar a formação de professores para as atividades profissionais no contexto da tendência moderna de informatização da educação. A formação profissional é baseada na inclusão de atividades inovadoras no processo educacional de uma universidade pedagógica que visa organizar a interação informacional criativa de alunos e professores no processo de domínio das tecnologias de e-learning. De acordo com as novas alterações da Lei Federal "Sobre a Educação", atualiza-se o problema da inclusão de tecnologias educacionais a distância nas escolas. No artigo, são definidos os rumos da formação profissional de professores para a educação a distância, e elencados os principais modelos de formação profissional de professores na área de tecnologias de educação a distância em estágio de formação em universidade pedagógica e formação avançada. Mas existem barreiras que impedem o uso de tecnologias de ensino a distância e e-learning no processo educacional. A diferença entre as tecnologias de educação a distância e a e-learning é se existe ou não uma cooperação direta entre o professor e o aluno. Se for feito com tecnologia da informação, meios técnicos, estamos a falar de e-learning. Se a interação é mediada, por meio da Internet, por exemplo, então isso é ensino a distância. Uma organização educacional tem o direito de usar uma ou ambas as formas de implementação em seu programa educacional. É importante preparar os futuros professores para o uso das tecnologias de ensino a distância nas atividades profissionais no processo global de informatização e digitalização da educação.

PALAVRAS-CHAVE: Barreiras. Condições sociais e pedagógicas. Gestão de qualidade. Tecnologias educacionais a distância. Norma. Tecnologias de informação.

RESUMEN: El artículo está dedicado a la problemática del uso de tecnologías de educación a distancia, que son barreras en el proceso educativo. Los autores investigan las posibilidades de tener en cuenta las características técnicas del funcionamiento de las tecnologías de educación a distancia y e-learning en la legislación, así como las condiciones y problemas del uso de tecnologías de educación a distancia y e-learning en el proceso educativo. El problema está en mejorar la formación de profesores para actividades profesionales en el contexto de tendencia moderna en la informatización de la educación La formación profesional se basa en la inclusión de actividades innovadoras en el proceso educativo de una universidad pedagógica orientada a organizar la interacción informativa creativa de los estudiantes. y docentes en el proceso de dominio de las tecnologías de elearning. De acuerdo con las nuevas enmiendas a la Ley Federal "Sobre Educación" se actualiza el problema de incluir tecnologías de educación a distancia en las escuelas. En el articulo se definen las orientaciones de la formación profesional del profesorado para la educación a distancia, se enumeran también las principales formas de formación profesional 
del profesorado en el campo de las tecnologías de la educación a distancia en la etapa de formación en una universidad pedagógica y formación avanzada. Pero existen barreras que impiden el uso de tecnologías de educación a distancia y e-learning en el proceso educativo. La diferencia entre las tecnologías de educación a distancia y la educación electrónica es si existe una cooperación directa entre el profesor y el alumno o no. Si se lleva a cabo y con el uso de tecnologías de la información, medios técnicos, estamos hablando de e-learning. Si la interacción está mediada, a través de Internet, entonces esto es aprendizaje a distancia. Una organización educativa tiene derecho a utilizar una o ambas formas de implementación de programas educativos. Es importante preparar a los futuros profesores para el uso de tecnologías de educación a distancia en actividades profesionales en el proceso global de informatización y digitalización de la educación.

PALABRAS CLAVE: Barreras. Condiciones sociales y pedagógicas. Gestión de la calidad. Tecnologías educativas a distancia. Estándar. Tecnologías de la información.

\section{Introduction}

Distance educational technologies provide wide opportunities for organizing the educational process, they add variety to the form of information flow, expand the number of students, remove the barriers of the territorial inaccessibility of the educational organization.

At the present stage, many areas of the use of distance educational technologies in modern schools are being implemented. Among them, the following can be noted: distance learning for children with disabilities; organizing distance monitoring of educational achievements of students; implementing distance learning technologies in additional education; organizing specialized training; conducting distance learning classes for children who miss school for reasons of illness and during quarantine; distance learning support for gifted children and students' research activities; organization of school virtual communication systems; the introduction of distance learning technologies in full-time education using blended learning technology, etc. (MUKHAMETSHIN; SALEKHOVA; MUKHAMETSHINA, 2019).

The possibility of implementing distance learning in the educational process is done by the teachers' readiness to apply distance educational technologies in their professional activities, to evaluate the potential and effectiveness of distance forms of working with students to solve didactic problems. This actualizes the special training of teachers in the field of organization and methods of distance education, mastery of communication tools and technologies in the information and educational system (AHMETSHINA; KADYJROVA; MUSINA, 2016). The didactic basis of distance education technologies is the active independent educational activity of students, therefore, the professional competence of the 
teacher in the process of distance learning is in the ability to plan, organize, control productive independent work; to motivate students to various types of independent educational activities using ICT tools; to model subject content in a multimedia, interactive form; to ensure the variability of the methods of presentation, development and consolidation of the studied educational material taking into account the individual approach (SKIBICKIJ; FADEJKINA, 2006).

\section{Methods}

The study is based on a comprehensive, multi-faceted approach to the study of conditions and barriers during the training of teachers in the implementation of distance learning technologies in modern education. The analysis of normative documents, real educational practice in a pedagogical university showed that the existing training of a future teacher in modern pedagogical education is so far focused mainly on the formation of its general information and didactic competence, and the formation of a future teacher's readiness for professional activities in the context of informatization of education, the implementation of distance learning can be characterized as fragmented, not having a systemic basis.

To solve the research tasks, the following methods were used: logical-historical analysis with the aim of identifying tendency of the information society and informatization of education development, the formation of distance learning and counseling in distance learning; theoretical analysis of philosophical, psychological, pedagogical and methodological literature on the research problem; system-structural analysis to simulate a methodological system; modeling the process of formation of readiness for the implementation of counseling situations in distance learning computer science; questioning, conversation, testing; expert assessment method, document analysis; pedagogical experiment (KARAMOVA, 2019).

\section{Results and discussion}

The appearance of new forms of implementation of educational programs contributes to the development of the educational services market in the global network, when educational institutions offer educational programs of varying lengths and contents, targeting different categories of students. Organizations engaged in educational activities provide, for some time, access to the student's information resources within the framework of the 
educational program and check the tasks performed by him with a specified frequency. In organized forums of individual organizations which are engaged in educational activities, it is supposed to discuss emerging issues between students with the participation of teachers. The use of distance learning technologies in the educational process has positive and negative sides both, problems that are barriers to the implementation of this project, therefore, it is important to determine the correct vector for the use of distance learning technologies, so the right to education could be guaranteed (SUKHOTIN; BELYAVSKY, 2013).

The antonym of the term "conditions" is the term "barriers". "A barrier is an obstacle to something" (OGURTSOV, 1986). This concept can also be applied in pedagogy to denote everything that hinders, restrains and, finally, reduces the effectiveness of training, education and personal development (SAFAROVA, 2019). Reducing the impact of barriers is already, in our opinion, one of the important conditions. Shevyrev (1995) points to the following psychological obstacles among other barriers: established stereotypes; weakened determination; lack of effective techniques and methods for developing alternatives, etc.

There are a number of barriers (problems) in the legal regulation of distance educational technologies, there are many of them, but we will focus on some of them, which are the most hindering distance learning.

1. The use of distance learning technologies in the educational process requires ensuring a secure exchange of data between the organization engaged in educational activities and students. So, if an organization engaged in educational activities has a digital certificate, the full use of which guarantees students verification of the authenticity of the certificate holder and, as a consequence, the authenticity of the resources placed by him, and also uses cryptographic data protection mechanisms that provide a secure connection between the provided resources and the students, then the organization that carries out educational activities protects both its own and the data of students, maximally preserving the right to education of the latter.

For example, information posted on the website of an educational organization cannot be compromised in the process of transferring data from a student to an educational organization or, vice versa, an intruder cannot be included. Otherwise, if the measures described above are not implemented or are partially implemented, participants in the educational process are at risk of fraud by intruders. A site can become official only if it is protected by a digital certificate. The educational organization has no obligation to receive it. Therefore, the educational organization, placing a certain resource, does not guarantee its authenticity and security of the information contained in it. 
2. Lack of technical support at the workplace of both the teacher and the student (especially for students in general education programs), because while equipment failures or communication networks and software failures the educational process is forced to stop. We are talking about the problems that arise during the organization of the system, its updating and maintenance, both from the educational organization, and about the problems of equipment, software and its updating on the student's side.

Moreover, the student may have questions related to the use of a resource posted by an educational organization, which can be provided in the form of a website with information about the curriculum, a data storage server, such as lectures, or a link to a live broadcast of a lecture or seminar, etc. Technical support is important in other cases, when you need to enter databases containing information on training courses that the student does not currently master and, accordingly, does not have access to, but the information within which he needs to complete the tasks (for example, the material learnt in the previous lesson).

All this requires the development and provision by the educational organization to the student with detailed and at the same time simple instructions for installing, updating the equipment and software necessary for working with the resource provided by the educational organization, as well as instructions for working with it. Along with the above it is necessary for an educational organization to provide an operational communication channel of technical support to the student in order to solve problems as soon as possible. Initiatively, some educational organizations provide such support (KARAMOVA et al., 2016).

3. So, the legislation in the field of sanitary and epidemiological welfare of the population contains regulatory standards in the field of the use of electronic computers in the educational process and requires compliance with the requirements for the equipment, its area, electromagnetic voltage (the number of units of equipment per area unit), etc. Problems arise due to outdated terminology and the neglect of new advances in electronics. For example, the term "video display terminals" is still used, which includes mobile phones. Legal uncertainty is created about how to organize a workspace, for example, using a tablet computer, smartphone, interactive table, etc.

Despite its seemingly breakthrough character, educational legislation, nevertheless, prevents the use of distance learning technologies in the educational process in some issues. A computer can only be used in points of the exam by participants in the state final certification who are not able to write on their own, who can only do work on the computer. Such a computer should be without access to the global network and not contain information on the subject which they pass. 
Thus, training can be completely built on the use of distance learning technologies without any full-time, classroom classes. This may be acceptable as a part of additional education. But when we talk about professional or higher education, even not mentioning school, it is a great danger to the quality of education. The task of educational organizations that determine the amount of compulsory classes of a teacher with a student is to prevent the transition exclusively to the plane of virtual relationship between the student and the teacher.

\section{Summary}

The solution of the indicated problems is possible with the strengthening of the social partnership of a pedagogical university, general educational organizations, regional virtual methodological associations. As a result, a complex of educational goals can be optimally achieved: a) that meets modern requirements professional development of working teachers (both university and school); b) increasing the efficiency of training future teachers in the system of higher education; c) the development of students in accordance with modern requirements for educational results in the process of cognitive activity based on the use of information technologies.

The positive point is that Federal Law N 273 does not contain restrictions on the development of either part of the main educational program in a foreign language. Accordingly, the use of foreign literature is also possible. When it comes to general education and textbooks which are recommended for use in the state-accredited educational programs for primary general, basic general, secondary general education, the federal list of textbooks has been approved. Educational organizations are entitled to choose textbooks only from this list, it is noted in the paragraph 1 of this law. If you open it, you can see in addition to textbooks in Russian only textbooks of among the three languages of the peoples of the Russian Federation: Tatar, Khakass and Yakut.

Due to the fact that distance learning has become increasingly popular in recent years, there is a need to standardize approaches to creating distance learning courses. Over the long history of the development of distance learning, Western distance learning institutions have successfully worked out the technology of this training. There are a number of international organizations working in the field of standardization, consortia and national programs, ministries of individual countries, closely cooperating in the development of elements of a systematic approach to building distance learning systems or any other training systems that operate on the basis of information technologies (ZHDANOVA; AFONINA, 2015). 
The creation of such a standard allows you to use a single approach to building a distance learning system, while filling it with different content. A promising direction for the development and improvement of distance learning in the Russian Federation is the study of the issue of creating a standard for distance learning, taking into account the positive experience of both the Soviet and Russian educational systems.

The domestic scientific literature has already expressed the opinion that among the problems that impede the effective use of distance learning technologies in Russian educational institutions, there is the problem of universities using software products created on the basis of various standards, which makes it difficult to efficiently exchange information between universities and creates difficulties for integration into the global e-learning system implemented on the basis of international standards.

The way out of this situation is in the development of a systematic approach to building computer training systems and the implementation of standards for their software and technological components, ensuring compatibility of systems and their elements, as well as their resistance to changes in the field of information technology and software.

\section{Conclusions}

So, we found out that in a modern university, within the framework of the educational process, the use of blended learning technologies is becoming more relevant. In accordance with the requirements of the Federal State Educational Standard of the third generation, the content of the subject and professional training disciplines of teachers must be presented on the educational portal. With such an organization of the educational process, effective conditions are created for the development of professional competence in the application of forms and methods of distance and blended learning (LAPCHIK, 2011).

Thus, the double entry of distance educational technologies into the professional training of future teachers at the level of content and at the level of organization of the educational process creates effective conditions for the development of relevant aspects of professional competence.

ACKNOWLEDGEMENTS: The work is performed according to the Russian Government Program of Competitive Growth of Kazan Federal University. 


\section{REFERENCES}

AHMETSHINA, G.; KADYJROVA, L.; MUSINA, K. The use of virtual reconstruction technology to prepare intending designers in Kazan Federal University. Turkish Online Journal of Design Art and Communication, v. 6, p. 3131-3140, 2016. DOI:

https://doi.org/10.7456/1060NVSE/132

KARAMOVA, K. H. Role of the "green" philosophy and bionics on the development of ecodesign clothing. Helix, v. 9, n. 4, p. 5204-5207, 2019.

KARAMOVA, K.; MUKHAMETSHIN, L.; IVANOVA, E., USMANOV, S. Issues of forming information skills of students in mathematics lessons through ICT. Journal Universidad del Zulia, v. 35, n. esp. 22, p. 994-1007, 2016.

LAPCHIK, M. P. From distance educational technologies to the system of innovative education. In: Modern education in the context of reform: materials of the II All-Russian scientific-practical conf. Krasnoyarsk, 2011. p. 18-22.

MUKHAMETSHIN, L.; SALEKHOVA, L; MUKHAMETSHINA, M. Using the Ims moodle system in the modern educational process. Journal of Philology and Culture, n. 56, p. 274279, 2019. DOI: https://doi.org/10.26907/2074-0239-2019-56-2-274-279

OGURTSOV, A. P. Historical types of discussions and the formation of classical science. In: The role of discussions in the development of science. 1986. p. 89.

SAFAROVA, M. Development of creative competence of an elementary school teacher in continuing education. European Journal of Research and Reflection in Educational Sciences, v.7, n. 12, 2019.

SHEVYREV, A. V. Creative problem solving technology (heuristic approach) or a book for those who want to think with their own heads. Belgorod, 1995.

SUKHOTIN. S. O.; BELYAVSKY, A. A. Organizational and legal support of e-learning with using distance educational technologies. Information Law, n. 3, 2013.

ZHDANOVA, A. I.; AFONINA, M. V. Harakteristika vozmozhnostej ispol'zovaniya avtomatizirovannyh informacionnyh sistem $\mathrm{v}$ ocenke kachestva obrazovaniya.

Pedagogicheskoe obrazovanie na Altae, n. 1, apr. 2015. Available:

http://journals.altspu.ru/pedagogical-education/article/view/199. Acess: 10 dec. 2020. 


\section{How to reference this article}

MUKHAMETSHIN, L. M.; KARAMOVA, K. K.; SALEKHOVA, L. L.; USMANOV, S. F. Barriers of teacher formation in the implementation of distance learning technologies in modern education. Revista on line de Política e Gestão Educacional, Araraquara, v. 25, n. $\begin{array}{llllll}\text { esp.1, p. 398-407, mar. 2021. e-ISSN:1519-9029. DOI: } & \end{array}$ https://doi.org/10.22633/rpge.v25iesp.1.14976

Submitted: 06/11/2020

Required revisions: $18 / 01 / 2021$

Approved: $23 / 02 / 221$

Published: 01/03/2021 